\title{
Semiotics of Roland Barthes in Symbols Systems of Javanese Wedding Ceremony
}

\author{
Mohamad Jazeri ${ }^{1} \&$ Susanto $^{1}$ \\ ${ }^{1}$ State Islamic Institute (IAIN) of Tulungagung, Indonesia \\ Correspondence: Mohamad Jazeri, State Islamic Institute (IAIN) of Tulungagung, Indonesia. E-mail: \\ mohamadjazeri69@gmail.com, damarsusanto53@yahoo.co.id
}

Received: May 21, 2020; Accepted: June 3, 2020; Published: June 18, 2020

\begin{abstract}
This study is aimed to explain the interpretation of symbols systems in Javanese wedding ceremony. The symbol patterns can be categorized into leaves symbols, vegetable symbols, flowers symbols, food and drinks symbols, Javanese traditional instrumental music (gending-gending), and thread of marriage processions. The data of this study were collected by in-depth interview techniques, participant observation, and documentation. The data were analyzed with the Miles and Huberman interactive models. Data analysis reveals that substantial meanings of the symbols in Javanese wedding ceremony are of advice, prayers, descriptions, parables, and responsibilities. The first, an advice for a bridge/a bridegroom is to have a well foundation, always to love each other, to become a reassuring spouse, to be considerate and think clearly, to have tender heart, and to respect their parents. The second, prayers are delivered in order that the bride and bridegroom have abundant lawful or halal fortune or wealth, have good offsprings, keep away from life barriers. The third, description means that the bridge looks like a beautiful queen and a bridegroom is associated to a handsome and dashing king. The fourth, a parable of marriage is alike to wade the ocean with big waves and storms. The fifth, a responsibility is due to a husband to make a hay or earn money and a wife to manage it then they work together to obtain the goal of marriage. The connotative meaning is flourished to become a myth that marriage ceremony is equipped with standard of symbols that will build the happy and everlasting marriage.
\end{abstract}

Keywords: symbol, meaning, marriage, javanese culture

\section{Introduction}

No society without culture, and no sustainable culture without supports of a society. Culture is the product of the consciousness and capability of the society. There are elements of culture, such as language, knowledge systems, social organizations, religious systems, and arts. From these elements are formed the culture that is adjusted in the design of traditional ceremonies. Among the traditional ceremonies revived much attention is the ceremony of human life periodicity.

In the Javanese entourage, life chain ceremonies that received much affection were birth, marriage, and death (Sedyawati, 2006). Of the three life orbit ceremonies that are most welcome with joy and celebrated with great excitement is the wedding ceremony. Social status and economic stability do have a great influence on the size of the marriage ceremony. However, no matter how small the wedding ceremony, it is always done with more thorough preparation and a rousing procession than other ceremonies.

In every ceremony, a community always uses symbols as a means of communicating the message or meanings conveyed accross the ceremony. As an animal symbolicum and homo semioticus, the presence of symbols is natural. It is caused by the symbol, which is present from the humans need to convey ideas, thoughts, messages, norms, rules, and hopes to each other. In their lives, humans are commonly associated with symbols comprising the language they use. As such, every human being is also a symbol that carries a certain meaning.

Eventually, the processions for the wedding ceremony also seems to be gradually adapted, especially in the part of simplifying the facilities and the process. Therefore, more modern Javanese people are infamiliar with the proceeding, facilities, and processions of their traditional wedding ceremonies, let alone in understanding the meanings lying in each symbol given in the wedding ceremony. 
Etymologically, the term symbol is derived from the Greek symbollein which means to match parts of items split or broken into two parts. They are called symboles which then develop into the word symbols. Symbols are also often referred to emblems. Therefore, some people equate the term symbol with an emblem.

Epistemologically, Ricouer defines symbols as forms that mark something else outside the embodiment of symbolic, secondary, and figurative forms, and which can be understood only through the first meaning. Symbols are all mental activities of humans, as well as language. Language is only one form of symbolic activity (Ricouer, 2017). While Geertz explains that symbols are objects, actions, events, properties that can act as a vehicle for a conception (Geertz, 1988, 2013).

To understand the meaning of the symbol, semiotics of Roland Barthes is used as a theoretical reference to analyze it. In semiotics there are two things to notice, namely signs and markers. For Saussure the sign is called referent or signified while the sign is called signifier. Similar to Peirce who termed interpretant for signified and object for signifier, the difference is that Saussure interprets "object" as a referent and mentions it as an additional element in the marking process. For example: when people say the word "dog" (signifier) in a curse tone, it is a sign of bad luck (signified). For Saussure, signifier and signified are a unity like two sides of a piece of paper (Sobur, 2002, 2004).

Sausure's thought on signs is passed on by Roland Barthes. He is interested in the complex way in which sentences are formed and the way in which the sentence forms a determined meaning, but the less interested in the fact that the same sentence could convey different meanings to people of different situations. For Roland Barthes, the interaction between the text with the personal and cultural experiences of its users, the interaction between the conventions in the text and the conventions experienced and expected by its users must receive attention. Barthes's notion is known as "order of signification", including denotation (the actual meaning according to the dictionary) and connotation (a double meaning born from cultural and personal experience) (Sobur, 2002). Here is the point of difference between Saussure and Barthes, even though Barthes still uses the signifier-signified term carried by Saussure.

In addition, further Barthes also sees another aspect of labelling, the "myth" that marks a society. Myth is the meaning of denotation in the second stage, namely the connotation meaning that has been agreed upon, and thus it becomes the meaning of the second stage denotation. In this stage comes the meaning of myth (Barthes, 2007). "Myth", according to Barthes, lies at the second level of signification, so that it lies after the sign-signifier-signified system is formed, the sign will become a new marker which then has a second sign and will form a new sign. In short, when a sign eventually has a connotation meaning and develops into a denotation meaning, it will then become a myth.

To explain Barthes's ideas on the meaning of semiotics, we can take an example like the banyan tree. A shady and dense banyan tree creates a "sacred" connotation because it is considered to be a dwelling place for spirits. The connotation of "sacred" then develops into a general assumption attached to the banyan tree symbol, so that the sacred banyan tree is no longer a connotation but turns into a denotation at the second level of meaning. At this stage, the "sacred banyan tree" is finally considered a myth.

In relation to the previous explanation, this study aims to reveal the meaning of symbols in Javanese traditional wedding ceremonies from the perspective of Roland Barthes's semiotics. Specifically, the purpose of this study is to explain (1) the meaning of the leaves symbol in Javanese bridal ceremonies, (2) the meaning of flower symbols in Javanese wedding ceremonies, (3) the meaning of fruit symbols in Javanese wedding ceremonies, (4) the symbol meanings of food and drink in Javanese wedding ceremonies, (5) the meaning of the gending symbol in Javanese wedding ceremonies, and (6) the meaning of Javanese wedding ceremony procession symbols.

\section{Method}

The meaning of the symbol system of Javanese Traditional Wedding Ceremony is a qualitative study. The data of this study are collected by in-depth interview techniques, participant observation, and documentation. Researchers conducted participative observation by joining the class and interviewed some teacher of Permadani to get the data. In addition, researchers used several module books used in learning Panatacara and Pamedhar Sabda in PERMADANI Tulungagung as documents. The module books are (1) Javanese Master of Ceremony, (2) Javanese Speech, (3) Javanese Literature, (4) Padhuwungan (Knowledge of Keris), (5) Ritual and Traditional Procedures of Javanese, (6) Javanese values, (7) Sekar Setaman (flowers for offerings), and (8) Sekar lan Gendhing (Javanese musical instrument). These books are only used among Permadani students and are not sold free of charge.

Data were analyzed with the Miles and Huberman flow models (Miles \& Huberman, 2014). The analysis model includes data collection, data reduction, data exposure, and verification. Data analysis is carried out since the data 
collection seems deemed saturated. While data reduction is carried out in the form of data classification, in accordance with the problem formulation and coding of the data. The data are then presented to be verified so that they get a final conclusion.

\section{Findings and Discussion}

Symbols in Javanese bridal ceremonies cover such as symbol of leaves, fruits, food-drinks, gending (Javanese musical instrument), and a series of wedding processions. The following are the results of the research and discussion.

\subsection{Leaves}

The leaves that are generally used as symbols in Javanese wedding ceremonies are Plantain leaves, Banyan leaves, Janur, Reeds, Apa-apa, Dhadhap, and Keluwih. These symbols contain the meaning of prayer, wishing for: (1) the bride is given the gift of happiness like the king's family, (2) the bride is able to build a family that can protect the extended family and community, (3) the bride gets the guidance of true light so that they can build a peaceful, cozy, and happy family, and (4) the bride does not have any problems in raising a family.

The symbols in the Javanese bridal ceremony seen from Roland Barthes Semiotics have three types of meanings, namely denotative meanings, connotative meanings, and mythic meanings. For denotative meaning, we can understand it easily. However, for the other two meanings we must understand it through the science of Semiotics, namely the science of the meaning of the sign. Plantain leaf, for example, is closely related to banana of plantain. Named the plantain because it is said that this banana is the favorite banana of the king and the royal people. The use of plantain leaves means a hope that the bride and groom can live in a happy life like a queen and a king (Sunartodipuro, 2018; Tim Dwija, 2018).

Banyan is a large tree with thick leaves, often used as a symbol of shelter and protection. The trees usually found in javanese villages are often considered sacred. Banyan trees are sacred because of its related myths and natural reservation. According to our informan, there are two things that make this tree considered sacred, i.e.1) there is a belief that the banyan tree is the home of spirits, and (2) this tree must be preserved because it is able to maintain the balance of the ecosystem. This is in line with Javanese local wisdom, namely hamemayu hayuning bawana (preserving the beauty of the world) (Endraswara, 2014). The following is the result of our interview with the chair person of Permadani association of Tulungagung.

Beringin adalah pohon yang besar dan rindang. Ia sangat cocok untuk berteduh. Pengunaan daun beringin sebagai simbol harapan agar pengantin dapat menjadi pengayom dalam keluarga ('Banyan is such a big and shady tree. Its leaves are used in the ceremony to symbolize a wish for the newly wed couple in order that they can be the protector of the family') (A1.05).

In book of Adat Tatacara Jawa (ritual and Javanese procedure), Sunartodipuro stated that the use of the Janur (mewly grown coconut leaves) is related to Javanese word meaning that janur means sejatine nur ('the true light'). So, the use of the leaf implies that God gives His light and gives His blessings to the bride and groom so that they can build a happy life physically and mentally (Sunartodipuro, 2018). In Arabic, we often call it sakinah (serene), wawaddah (full of love), and rahmah (full of affection). The following is result of interview with Permadani secretary.

Dalam upacara pengantin Jawa, janur bermakna do'a agar Tuhan menurunkan hidayah-Nya supaya pengantin berdua mampu membina rumah tangga sesuai dengan tuntunan agama. Tujuan berkeluarga adalah agar mereka Sakinah, mawaddah, dan rahmah ('In javanese wedding ceremony, janur means a prayer wishing for the guidance of God, by which the newly wed couple can hopefully foster family life based on religious precepts. The purpose of marriage is forming a religiously happy family, named as sakinah (serene), wawaddah (full of love), and rahmah (full of affection)'. (A1.06).

Janur or newly grown coconut leaf is often used in many religious and cultural events. In Karanganyar, central Jawa, the people wear a belt of janur as a symbol of asking to God to handle the natural disaster. On the other hand, this tradition reminds them to keep a local wisdom of maintaining ecosystem balance to avoid natural disaster (Lestari, Purnomo, Komariah, \& Wibowo, 2018). In Bali, the people use janur in wedding ceremony and welcoming Galungan day. High demand for janur makes some Balinese develop janur handcraft as a business (Martini, Priliandani, \& Wahyudi, 2019).

Another leaf which also complements the Javanese bridal ceremony is the betel leaf. Betel is a leaf from a plant whose stems are elongated and creep up. The taste of the leaves is normal for "nginang". If you turn it over, the color is different, but it tastes the same. Even though they are different (origin, gender, etc.), they are one, one taste, intention and work. The meaning of the use of Betel leaves in a bridal ceremony is a prayer with the result 
that the bride and groom always unite in creativity (cipta), taste (rasa), intention (karsa), and work (karya) (Tim Dwija, 2018).

Daun sirih merupakan symbol harapan agar pengantin berdua meskipun berbeda, bisa menjalin kebersamaan dalam cita, rasa, karsa, dan karya menuju keluarga yang bahagia dan sejahtera ('Betel leaf symbolizes a wish for the newly wed couple in order that they can blend and cooperate in creativity, taste, intention, and work') (A1.06).

In fact, betel leaf is of a benefit in medical world since it contains cetylpyridinium chloride (CPC), functioning as a hindrance for the growth of infecting bacteria. The medical product utilizing betel leaf is rinsing liquid to prevent and protect teeth from tartar and bad smell. (Toar, Posangi, \& Wowor, 2013). In addition, betel extract is mainly used for curing as well as preventing dengue fever. It functions to break down life cycle of Aedes aegypti larvas causing such a disease and it is even more effective to kill them (Mohammad, 2006). At last, the benefit of betel leaf extract is that it can be utilized as antiseptic gel and mouth wash liquid, which both effectively kill bacteria and viruses triggering SARS and bird influenza (Putri, 2010; Sari \& Isadiartuti, 2006; Syahrinastiti, Djamal, \& Irawati, 2015).

The next leaf is alang-alang (imperata cylindrica), which is phonetically similar to javanese word alangan, which means 'obstruction'. It is also true to the local tree named kara, which also phonetically resembles to javanese word sakara-kara, also meaning 'obstacle', and so is the word apa-apa, which means 'at all' in Javanese.

In Javanese, alang-alang is associated with the word alangan, which means an obstruction and a hindrance. As such, it contains a meaningful prayer that the bride and groom in living married life can be free from obstruction or obstacles. In addition, it suggests that, as the chararacteristics of this reed, the newly wed couple may immediately raise up again even when they found any misfortunes like the alang-alang, which sometimes tumble down, hit by the wind, and soon they rise up again. This implies that despite the problems faced by the bride and groom, it is expected that they will survive and immediately, go on achieving the goals of life.

About this reed, there is a myth which is flourished that leaf of reeds is to repellent danger. If the house or the place is put on reed leaves, jinn and spirits do not dare to disturb. Therefore, in the Javanese bridal wedding, reed is used and placed in front of the gate in order the bridal ceremony will not be disturbed or hindered. The secretary of Permadani states:

Menurut mitos, daun alang-alang adalah daun penolak bahaya. Jin dan mahluk halus takut dengan alang-alang. Dalam upacara pengantin Jawa alang-alang digunakan dan dipasang di depan gerbang agar upacara pengantin tidak mendapat gangguan dan rintangan (In javanese myth, alang-alang tree is the blocker of any coming harm. In the javanese wedding ceremony, it is displayed and installed in front gate in a hope that the process of ceremoy can run smoothly, free from any possible obstructions and hindrances'.) (A1.11).

So far, alang-alang (imperata cylindrica) has been assumed as the 'disturbing' plant. In fact, it benefits much in medical world, as reported by Kebon Raya Bogor team (Hidayat \& Rachmadiyanto, 2017), that is its roots can be utilized as antihipertension medicine (Ruslin et al., 2013).

The serep (Erythrina lithosperma Miq) leaf is used as one of Javanese bridal ceremonial equipment because the word serep is synonymous with cool. So, the use of a serep leaf is a symbol of hope and prayer so that the bride and groom always live in a cool, assured, calm, peaceful, and happy family atmosphere.

Daun dhadhap serep dalam bahasa Jawa berarti dingin. Ini berarti bahwa pengantin berdua diharapkan mampu membina keluarga yang ayem dan tenteram (hayom, hayem, miwah tenterem) (The serep leaf, as its name suggests, means 'cool' in javanese. It means that the couple are expected to be able to foster 'a socially cool' family, surrounded by peaceful and harmonious social atmosphere' (A1.15).

Such a leaf is used be one of the ingredients in javanese wedding ceremony to symbolyze the cool atmosphere, as suggested by its name. Thus, its use suggest a wish for the weds that they lead a peaceful life, far from marital conflict.

Erythrina lithosperma Miq grows easily in villagers neighborhood and it is frequently used for traditional medicine. The current study shows that this plant contains antibacterial blend that can hinder the growth of Salmonella typhi bacteruim (Kholidha, Suherman, \& Hartati, 2016). Furthermore, it also contains alkaloids, flavonoids and tannins, which are effective for recovering fever, stomachache, inflamation, and cough. It contains antibacterial activity hindering the growth of escherichia coli ATCC 8939 (Rahman, Firmansyah, \& Setyabudi, 2019). 


\subsection{Flowers}

In the book of Sekar Setaman, the flowers that become symbols in the Javanese bridal ceremony include roses, jasmine, kantil, and kembar mayang. These symbols mean hope and prayer that the bride and groom are always to live in love (roses), be together in joy and sorrow (kantil), and to please and to scent the family's name (jasmine) (Sunartodipuro, 2018; Tim Dwija, 2018). One of Permadani teachers state as below:

Bunga yang digunakan dalam upacara pernikahan adat Jawa adalah kembang triwarna, yaitu mawar, melati, dan kantil. Ketiga bunga tersebut mengandung makna harapan supaya pengantin berdua berbicara manis, menjagaa nama harum keluarga, dan selalu bersama dalam suka dan duka 'The flower used for javanese wedding ceremony is three-coloured flowers, a mixture of rose, jasmine, and kanthil.Those three flowers suggest a wish that the weds get along well by warm and sweet interaction, keep the family dignity and always get together in joy and grief' (B2.03).

Based on the above data, it can be seen that roses, jasmine, kantil, and have denotative, connotative, and mythical meanings. Roses are flowers with thorny trees and beautiful flowers. The color of the flowers is also various. In general, roses are symbols of love. Myth says that the rose is the name of a very beautiful queen, but she is arrogant and evil (Sophia, bahasa.tripod.com).

Aditya Eka Prawira (m.liputan6.com) explains the meaning of roses based on the color they have. First, red roses are a symbol of true love, romantic. This rose is suitable to be given to a lover as an expression of one's love to his lover. Second, the yellow rose is a symbol of friendship, joy, and healing. Yellow roses can be given to people who are close as friends, not lovers. Third, the purple rose symbolizes a splendor. This type of rose is suitable for someone who is charming at first sight. Fourth, pink roses represent a sense of love, gratitude, and deep appreciation. This type of rose is usually addressed by people as a gratitude. But this pink rose is also suitable for friends or relatives who are sick as a sign of tenderness and admiration. Fifth, white roses describe true love, purity, innocence, and sympathy. The white color also shows the atmosphere of spirituality. This rose can be used on the wedding day, but also suitable on the day of death. Sixth, orange rose; mix yellow and red. This type of rose indicates desire, passion and enthusiasm. This rose says "I'm proud of you" which is perfect for honeymooners.

Next is jasmine flower. Jasmine flowers emit a soft fragrance that gives the impression of soft, comfortable, and calm. This flower is often used as a symbol of sanctity, purity, simplicity, and beauty. The myth that developed in Javanese society, jasmine is a match mate. If someone who is still single steals (takes away) jasmine flowers worn by the bride, he will soon be found with his soul mate.

The following flower is kantil or white cempaka. Kantil means sticky, attached. This is advice and hope that the bride and groom always be together in joy and sorrow and will not be separated by anything but death (Tim Dwija, 2018). In Java, there is also a myth that kantil flowers are believed to be able to detect the sanctity of the bride. If the bride is not chaste, the kantil flowers will not smell nice when it is worn, and the flower petals open or vice versa.

Denotative meaning of kembar mayang is twin flowers or similar flowers. This shows the bride and groom must have the same feelings, heart, and will build a happy family. The myth that developed in Javanese society states that kembar mayang are kalpataru, jayandaru, dewandaru trees assembled by nymphs in heaven (Tim Dwija, 2018).

Rose is a notoriously decorative flower, assumed as 'The Queen of Flower'. This flower is used for the symbol of religiousity and spirituality in any walk of culture. It is mostly grown in the tropical and sub-tropical regions like China, middle east, and eastern part of Europe (Mill, 2010). In medical world, rose is also well known as the therapy for hypertension, especially for its good fragrance. The blood pressure of patients can be gradually cured and get normal through rose-extract therapy if it is routinely done based on docter's prescription (Kenia \& Taviyanda, 2013).

So far, javanese people have still utilized jasmine as tea fragrance and decoration. Still can the jasmine fragrance be potentially processed into atsiri oil, which is economically of high price (Sani, Rachmawati, \& Mahfud, 2012). The fragrance of jasmine has been mostly utilized as medical benefits. Several research findings show that its fragrance can alleviate or even cure sleep disorder ,commonly suffered by the elders (Kusnaidi, Haryanto, \& Makhfudli, 2011).

In medical world, Kantil flower, or also called cempaka, benefits mothers of 50 years of age who undergo menapouse. The diminishing esterogen hormon production may cause the increase of free radicals. The amount of antyoxidant does not balance with the amount of free radicals in the body, generating what so called oxidative 
stress for women. In such condition, kanthil extract can help to mitigate the stress by reducing the high degree of free radicals (Fajria Maulida \& Sri Wahyuni, 2018). The meaning the symbols of leaves and fruits is as below.

Table 1. The meaning of leaves

\begin{tabular}{lll}
\hline No & Symbols & Meaning \\
\hline 1 & Janur kuning & Nur/cahya (bright) \\
2 & Cengkir & Kencenging pikir (steady mind) \\
3 & Tebu & Antebing kalbu (steady heart) \\
4 & Gedhang raja & Ginadhang raja (hope as happy as a king) \\
5 & Daun beringin & Pengayoman (shelter) \\
6 & Andong-puring & Nyadhong peparing (hope for grace) \\
7 & Daun kluwih & Luwih (asking for convenience) \\
8 & Wulen pari & Boga (enough food) \\
10 & Daun maja & Aja (no) \\
11 & Alang-alang & Halangan (obstacles) \\
12 & Apa-apa & Sawiji apa (at all) \\
\hline
\end{tabular}

\subsection{Fruits}

Fruits used as symbols in Javanese bridal ceremonies are cengkir (young coconut), rice, plantain, saba banana, kluthuk banana, and golden banana. The meanings of these symbols are (1) advice that the bride and groom must focus, be steady, and be sincere (cengkir: think of the mind) in undergoing a married life, (2) prayer, that all need of the bride and groom will always be fulfilled by the Almighty God, and (3) description of the bridegroom has gone and found the bride of the princess (Raja saba kepethuk emas).

Bananas in Javanese are called gedhang which are the same as the word gadhang (hope), while the king means an authoritative, powerful, respected, and abundant wealth. The meaning contained is the hope that the bride and groom can live together like a happy king, have the authority, power, and abundant wealth. In addition, many bunches in plantain also is intended that the bride and groom will soon be blessed with children.

This kind of banana is called pisang raja 'the banana king' since it was assumed as the favorite banana comsumed by the Javanese King and the royal family in the past. This banana is more special than others because it has large leaves, more fruits, and sweeter taste. The use of its leaves symbolizes a hope that the weds can lead a future family life as glorious and happy as the life of a king and queen.

The raja ate and Ambon bananas contain high carbohydrate and potassium that can increase the glucose in blood. Consuming these bananas can reduce muscle fatigueness before getting exercise. In a study on a number of athletes of 17-18 years of age, the consumption of these bananas before exercise can help them to free from muscle fatigueness (Lone, Ardiaria, \& Nissa, 2017), Since the it suggests positive name, raja banana is also used as a symbol in Kasada ritual ceremony in Tengger community (Pramita, Indriyani, \& Hakim, 2013).

Young coconut in Javanese is called cengkir. The word cengkir according to Javanese tradition is an acronym of the word kencenging pikir (firm, steady mind). The meaning conveyed from the use of the ivory cengkir symbol is that the bride and groom live together in life are always based on a firm stance (firmly thought), not swayed by the situation in order to achieve a happy and valuable life. Complement of clove is sugar cane which means resolute heart (good heart). So, marriage must be with a firm mind and a good heart (Sunartodipuro, 2018).

The purpose of the use of rice as a symbol in Javanese wedding ceremonies is that the bride and groom imitate the philosophy of rice, that is, the more filled the more bowing, the older the humbler. Another meaning is, because rice is a staple of Javanese food, the symbol of rice contains the hope that the bride and groom in building a family are always blessed with sufficient fortune by Almighty God.

The flourished stories in the community say that rice is a plant which grows from the body of Dewi Sri. Dewi Sri was a daughter of a king who was bewitched by her stepmother to become a snake. Another story states that Dewi Sri is the wife of Lord Vishnu. Therefore, Dewi Sri is known as the goddess of fertility or the goddess of rice. Old Javanese people often hold celebrations after the harvest as an expression of gratitude to Dewi Sri. Central Java Language Center (Tim Balai bahasa. www.balaibahasajateng. web.id) explained that rice in Javanese traditional wedding ceremonies means that both the bride and groom in carrying out domestic life are always fulfilled their food needs. 


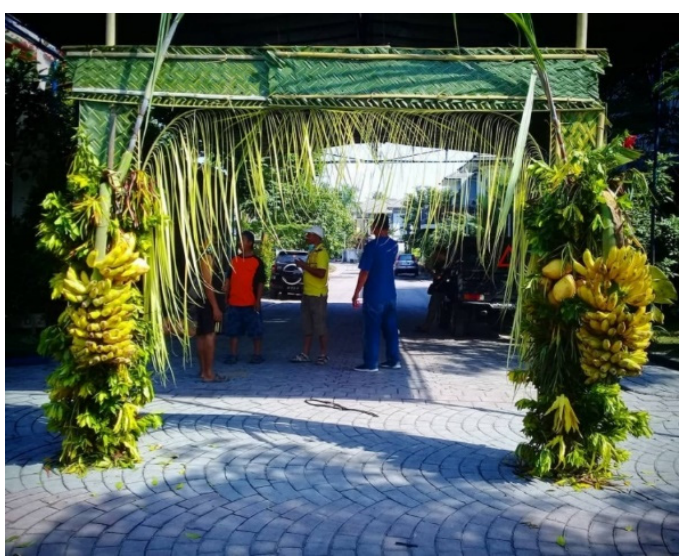

Figure 1. Wiwara/Gapura (Gate)

\subsection{Food and Drinks}

There are several types of food and drink that must be available in javanese ceremony. Such types of food and drink are used to symbolyze a prayer, wishing for the endless loyalty, considerateness, and togetherness in marriage for both bride and groom in any life situation. Here is the interview with the scretary of Permadani association:

Makanan dan minuman yang ada dalam upacara pernikahan Jawa adalah nasi, air jernih, air kelapa, jadah, dan wajik. Makannya adalah harapan agar pengantin mencari rejeki yang halal, berpikir dan berhati jernih, serta selalu bersama dalam suka dan duka 'Food and drinks that are usually present in Javanese wedding ceremonies are rice, pure water, coconut water, jadah, and wajik. The meaning is that the bride and groom seek halal fortune, using a clear mind and a tender heart, and always being together in joy and sorrow' (D4.01).

Colored rice or colorful food served for bridal in feeding each other is a suggestion that the bride and groom look for halal wealth and eat halal food. In addition, the rice used for the procession of dulang (feed the food) is a suggestion that the bride and groom always get along well, love each other despite facing various trials in married life (Tim Dwija, 2018).

Furthermore, clear water in Javanese wedding ceremonies is a symbol of hope that the bride and groom in living their married life will always be based on a clear mind and a tender heart so that family life can be peaceful, peaceful, and happy (Sunartodipuro, 2018; Tim Dwija, 2018).

In Javanese culture, water is also a symbol of life and smoothness or flexibility. Water is a symbol of life because of the large role of water in life. It can even be said that without water there would be no life. In the Qur'an it is stated that God made everything alive because of water (waja'alna min al-maa'i kulla syai'in hayyi). In addition, water is also a symbol of flexibility. Water always follows the shape of the vessel which holds it. Inserted glass, glass-shaped water, inserted bowl-shaped bowl, and so on. This implies that the bride and groom must be able to adjust to the situation and conditions in which they are. Thus, they can accept and be accepted by anyone and anywhere.

Similar to clear water is coconut water. Coconut water is water derived from coconut fruit. Coconut water is holy, clean, and healthy. This is a symbol of the holiness and cleanliness of the bride's intention to build a home. Coconut water is clean and fresh. It is pure without mixture. Coconut water illustrates the cleanliness of the intentions and purity of the love of the bride and groom.

Uli and wajik are two food made from glutinous rice. Sticky rice is a type of rice which when cooked is stickier than ordinary rice. Jadah and wajik are a special meal in a bridal ceremony. Because of its sticky nature, the two food are both illustrated as advice and prayers so that the bride and groom always love each other, be amicable, harmonious, calm-peaceful and are not easily separated by any temptation.

\subsection{Javanese Traditional Instrumental Music (Gending)}

Traditional javanese music playing along with the process of wedding ceremony typically consists of about 10-11 categories, depending on the choice of the Master of Ceremony (MC). The following is the result of interview with the teacher of Sekar lan Gending 'song and music': 
Saya biasanya menggunakan beberapa gending untuk mengiringi prosesi pernikahan. Gending tersebut adalah ketyang sangyang, ketawang puspawarna, ilir-ilir, kodok ngorek, larasmaya, wilujeng ladrang, dhempel mijil, sri narendra, and umbul donga 'I usually play some gending to accompany the Javanese bridal ceremony procession included ketyang sangyang, ketawang puspawarna, ilir-ilir, kodok ngorek, larasmaya, wilujeng ladrang, dhempel mijil, sri narendra, and umbul donga' (E5.01).

These songs have the meaning of worshiping the majesty of God Almighty (ketawang sangyang), describing the beauty of the bride (ketawang puspawarna), describing the journey of the suba manggala (ilir-ilir), describing the happiness of the bride and groom (kodok ngorek), describing the beauty of the ceremony (larasmaya)), describing togetherness and eternal love (mijil dhempel), and prayers that God bless the bride and groom so that they are able to foster a sakinah family (peaceful), mawaddah (full of love), and rahmah (full of affection).

Based on the Brathes semiotics, gendhing has denotative, connotative, and mythical meanings. For example, Ketawang Sangyang intends to ask the Almighty to give His blessings to the bride and groom and all those present at the ceremony. Puspawarna describes the atmosphere and circumstances of the bride who entered the ceremony area. The meaning contained is for the bride and groom both fragrant and harmonious in entire life so they can foster a happy family.

Furthermore, Ilir-ilir means fans created by a sunan. Ilir-ilir is the hope that the bride will be able to ignite the fire of enthusiasm to struggle and to build a happy family then be able to reduce anger that makes the household atmosphere becomes chaos. In addition, ilir-ilir also contains advice for all of us to live well according to God's command and always try to achieve a better life in order to get happiness in living in the world and the hereafter.

The next song is the Kodok Ngorek. This song symbolizes that the bride and groom both feel happy because they are granted a gift from God in the form of a mate they love. Then it is proceeded with Larasmaya gending. This song contains messages of beauty, harmony and smoothness of life obtained by the bride and groom.

Further, Ladrang Wilujeng means gending of ladrang type that includes invoking for the safety of Almighty God. Ladrang Wilujeng contains advice to the youths to prepare themselves to achieve a prosperous life and good fortune.

Hereinafter, Mijil dhempel means to come together. It intends, perhaps the bride and groom will always band together and harmonious in order that they can achieve a happy life and soul in building a home. The following one is Sri Narendra used for Kanarendran carnival. Meaning, the bride and groom are expected to have the qualities of a king who protects, nurtures, and loves his people. Finally, Umbul Dongo is offering prayers to Almighty God. This music is a prayer request to Almighty God to always bestow His gift and give the bride and groom a happy family.

Regarding this gending, Endraswara (2014) explains literature and gending are mystical vehicles when humans want to unite with God. By quoting Serat Sastra Gending by Sultan Agung, he said that literature is a delicate figure, cannot be seen while gending can be sensed through its beauty. So, literature will be easily impressed through gending (Endraswara, 2014).

\subsection{Ceremonial Procession}

In Javanese wedding ceremony, there are a series of processions such as panggih (bride meeting), kacar-kucur (giving living), sungkem (worshiping parents), and some others. The foolowing is interview result with Permadani secretary.

Ada beberapa prosesi dalam adat pernikahan Jawa. Prosesi tersebut adalah panggih (pertemuan), siningepan sindur, bobot timbang (timbang pengantin), tanem jero, kacar-kucur, ngunjuk toya wening (minum air jernih), sungkem, kirab kanarendran, and kirab kasatrian 'There are a series of processions in Javanese wedding ceremonies, namely the bridal gathering, siningepan sindur, bobot timbang, tanem jero, kacar-kucur, drinking pure water, sungkem, kirab kanarendran, and kirab kasatrian' (F6.02).

Bridal gathering expresses the union of the bride and groom to start a new life that should be a lot of struggle in achieving goals, i.e. physical and spiritual happiness. Sindur is a prayer that expectantly the bride and groom in living a family's life will always receive guidance thereby they are always in the truth and kept away from infirmity.

Weighing is a symbol that the bride and groom already have a balance in various ways; descendant, education, wealth, age and love. In addition, they also get the same love from their parents. Tanem Jero is a symbol that the bride and groom have been blessed to become a married couple. Kacar-kucur is a symbol that in a Javanese family, a man is obliged to earn a living for the family. Dulang-dulangan (feeding each other) is a symbol that they work together, love each other, appreciate each other, respect each other, despite encounter various trials. Drinking clear 
water (ngunjuk toya wening) is a symbol for all decisions through family life, always based on a clear mind and a tender heart. Sungkem is implied that to achieve a happy life in fostering a family, children must always adhere parents and ask for their parents' approval (Suwarna, 2009).

The Kanarendran carnival is a symbol that a king and empress not only live luxuriously in the royal palace, but also agree to associate with the people, conceive the fate of the people, understand their suffering and then undertake policies that can overcome the problems faced by the people. Lastly, in the case of kasatrian carnival is aimed that king and empress, husband and wife must be organized to work together to build a happy home.

\section{Conclusion}

Taxonomically, the symbol system in Javanese bridal ceremonies can be categorized into symbols in the form of leaves, flowers, fruits, food-drinks, gending 'javanese traditional music', and sequences of wedding processions. These symbols culturally provide denotative, connotative, and mythical meanings.

The leaves commonly used as symbols in Javanese wedding ceremonies are Plantain leaves, Banyan leaves, Janur 'newly grown coconut leaves', Reeds, and some locally javanese leaves such as Apa-apa, Dhadhap, and Keluwih. In addition, the local flowers that are symbolically used in the Javanese bridal ceremony include roses, jasmine, kantil and kembar mayang. The local fruits utilized as symbols in Javanese bridal ceremonies are cengkir (young coconut), rice, plantain, and various local bananas like saba, kluthuk and emas. Food and drinks that are usually present in Javanese wedding ceremonies are rice, pure water, coconut water, and local cakes traditionally called jadah, and wajik. The music accompanying the Javanese bridal ceremony procession are those of ketawang sangyang, ketawang puspawarna, ilir-ilir, kodok ngorek, larasmaya, wilujeng ladrang, dhempel mijil, sri narendra, and umbul donga.

Semiotically, the meanings of these symbols are, first, of advices for the spousal couples as to supply themselves well, to always love to one another, to be each other's comforters, to be considerate, and to respect their parents. Secondly, of a prayer for the bride and groom in order to be provided with self-sufficiency in lawful livelihood, to be granted with offspring, and kept away from all hindrances. Third, of description that the beautiful bride is like a queen and the handsome groom looks like a brave king. Fourth, of the parable that marriage is like wading an ocean encounters lots of waves and storms. Fifth, of the responsibility in which the husband is to earn a living and the wife is to manage it in such a way that they will work together to achieve the ideals of marriage. This connotative meaning then flourished into a myth and belief that such a marriage ceremony equipped with a standard symbol system will build a happy and lasting marriage as the wish.

\section{References}

Barthes, R. (2007). Myth today. In Stardom and celebrity: A reader. https://doi.org/10.4135/9781446269534.n5

Endraswara, S. (2014). Mistik Kejawen: Sinkretisme, Simbolisme, dan Sufisme dalam Budaya Spiritual Jawa. Yogyakarta: Narasi.

Fajria, M. L., \& Sri, W. E. (2018). UPAYA MENURUNKAN RADIKAL BEBAS DENGAN EKSTRAK BUNGA CEMPAKA PADA TIKUS MODEL MENOPAUSE. Gaster | Jurnal Ilmu Kesehatan. https://doi.org/10.30787/gaster.v16i1.238

Geertz, C. (1988). Interpretation of Cultures: Selected Essays by Clifford Geertz. Journal of Comparative Physiology B. https://doi.org/10.1007/BF00695328

Geertz, C. (2013). Religion as a cultural system. In Anthropological Approaches to the Study of Religion. https://doi.org/10.4324/9781315017570

Hidayat, S., \& Rachmadiyanto, A. N. (2017). Utilization of Alang-Alang (Imperata cylindrica (L.) Raeusch.) as Traditional Medicine in Indonesian Archipelago. Proceedings The 1st SATREPS Conference.

Kenia, N. M., \& Taviyanda, D. (2013). Pengaruh relaksasi (aromaterapi mawar) terhadap perubahan tekanan darah pada lansia lipertensi. Jur. STIKES. https://doi.org/10.1001/jama.2013.284427

Kholidha, A. N., Suherman, I. P. W. P., \& Hartati. (2016). Uji Aktivitas Ekstrak Etanol Daun Dadap Serep ( Erythrina lithosperma Miq ) sebagai Antibakteri terhadap Bakteri Salmonella typhi. Issn: 2339-1006.

Kusnaidi, H., Haryanto, J., \& Makhfudli, M. (2011). Aromacare Melati Meningkatkan Pemenuhan Kebutuhan Tidur pada Lansia. Jurnal Ners. https://doi.org/10.20473/JN.V6I2.3991

Lestari, E., Purnomo, S. H., Komariah, \& Wibowo, A. (2018). Sabuk Janur: Tools to move community participation in reducing natural disasters and environment (case study at Lawu mount slope in Indonesia). IOP Conference Series: Earth and Environmental Science. https://doi.org/10.1088/1755-1315/142/1/012071 
Lone, V. F., Ardiaria, M., \& Nissa, C. (2017). PERBEDAAN EFEKTIVITAS PEMBERIAN PISANG RAJA DAN PISANG AMBON TERHADAP INDEKS KELELAHAN OTOT ANAEROBIK PADA REMAJA DI SEKOLAH SEPAK BOLA. Journal of Nutrition College. https://doi.org/10.14710/jnc.v6i4.18787

Martini, R., Priliandani, I., \& Wahyudi, A. (2019). Program Kemitraan Masyarakat Pengembangan Usaha Kerajinan Janur di Kabupaten Badung. International Journal of Community Service Learning. https://doi.org/10.23887/ijcsl.v3i4.21850

Miles \& Huberman (2014). Qualitative data analysis: An expanded sourcebook (3rd ed.). In Qualitative data analysis: An expanded sourcebook (2nd ed.).

Mill, R. (2010). MAWAR. Kantor Deputi Menegristek Bidang Pendayagunaan Dan Pemasyarakatan Ilmu Pengetahuan Dan Teknologi.

Mohammad, F. (2006). Perbandingan Efektivitas Abate Dengan Ekstrak Daun Sirih ( Piper Betle ) dalam Menghambat Pertumbuhan Larva Aedes aegypti. Disertasi Doctoral Fakultas Kedokteran Universitas Diponegoro.

Pramita, N. H., Indriyani, S., \& Hakim, L. (2013). Etnobotani Upacara Kasada Masyarakat Tengger, Di Desa Ngadas, Kecamatan Poncokusumo, Kabupaten Malang. Journal of Indonesian Tourism and Development Studies.

Putri, Z. F. (2010). Uji Aktivitas Antibakteri Ekstrak Etanol Daun Sirih (Piper betle L.) terhadap Propionibacterium acne dan Staphylococcus aureus Multiresisten.

Rahman, A. A., Firmansyah, R., \& Setyabudi, L. (2019). AKTIVITAS ANTIBAKTERI EKSTRAK ETANOL DAUN DADAP SEREP (Erythrina lithosperma Miq.) TERHADAP PERTUMBUHAN Escherichia coli. Pharmacoscript. https://doi.org/10.36423/pharmacoscript.v1i1.105

RICOUER, P. (2017). Prefácio ao “Essais hérétiques: sur la philosofie de l'histoire”, de Jan Patočka. PHENOMENOLOGICAL STUDIES - Revista Da Abordagem Gestáltica. https://doi.org/10.18065/rag.2016v22n2.15

Ruslin, Asmawi, M. Z., Rianse, U., Sahidin, I., Dhianawaty, D., Soemardji, A. A., \& Amalia, L. (2013). Antihypertensive activity of Alang - Alang (Imperata cylindrica (L.) Beauv. root methanolic extract on male Wistar rat. International Journal of Research in Pharmaceutical Sciences.

Sani, N. S., Racchmawati, R., \& Mahfud. (2012). Pengambilan minyak atsiri dari melati dengan metode enfleurasi dan ekstraksi pelarut menguap. Jurnal Teknik POMITS.

Sari, R., \& Isadiartuti, D. (2006). Studi Efektivitas Sediaan Gel Antiseptik Tangan Ekstrak Daun Sirih (Piper betle Linn.). Majalah Farmasi Indonesia.

Sedyawati, E. (2006). Budaya Indonesia: Kajian Arkeologi, Seni, dan Sejarah. Jakarta: Raja Grafindo Persada.

Sobur, A. (2002). Bercengkerama dengan Semiotika. Mediator: Jurnal Komunikasi.

Sobur, A. (2004). Analisis Teks Media: Suatu Pengantar untuk Analisis Wacana. In Analisis Semiotik dan Analisis Framing. https://doi.org/10.1177/1524838007302594

Sunartodipuro, T. (2018). Adat Tatacara Jawi. Tulungagung: Permadani.

Suwarna. (2009). Bahasa Pewara. Yogyakarta: Pustaka Pelajar.

Syahrinastiti, T. A., Djamal, A., \& Irawati, L. (2015). Perbedaan Daya Hambat Ekstrak Daun Sirih Hijau ( Piper betle L. ) dan Daun Sirih Merah ( Piper crocatum Ruiz \&amp; Pav ) terhadap Pertumbuhan Escherichia coli. Andalas. https://doi.org/10.25077/jka.v4i2.265

Tim Dwija. (2018). Renggeping Wicara. Tulungagung: Permadani.

Toar, A. I., Posangi, J., \& Wowor, V. (2013). DAYA HAMBAT OBAT KUMUR CETYLPYRIDINIUM CHLORIDE DAN OBAT KUMUR DAUN SIRIH TERHADAP PERTUMBUHAN STREPTOCOCCUS MUTANS. JURNAL BIOMEDIK (JBM). https://doi.org/10.35790/jbm.5.1.2013.2639

\section{Copyrights}

Copyright for this article is retained by the author(s), with first publication rights granted to the journal.

This is an open-access article distributed under the terms and conditions of the Creative Commons Attribution license (http://creativecommons.org/licenses/by/4.0/). 